\title{
高次スペクトルを用いた掁動系における実験解析
}

\author{
○正 松本 宏行（ものつくり大）, 大石 久己（工学院大）, 山川 新二（工学院大）, \\ 芝崎 達朗（工学院大），村岡 広基（工学院大）
}

\section{Experimental analysis by higher order spectra}

\section{Hiroyuki MATSUMOTO, Hisami OHISHI, Shinji YAMAKAWA, Tatsuro SHIBAZAKI and Hiroki MURAOKA}

Institute of Technologists, Dept. of Manufacturing

Maeya333, Gyoda, Saitama, 361-0038 Japan

We suggested a Higher Order Spectra(HOS) as new identification technique in the non-linear vibration system to receive irregularity input. we carry out an experiment non-linear vibration using the HOS and analyzed it and produce the improvement model with the magnet as an experiment model, and we performed the examination, and these are the main point of this report.

Key Words :Higher -order -Spectra, Bispectrum, Nonlinear vibration ,Random vibration, Identification

\section{1. 粕 言}

機械構造物に存在する現象はガ夕,摩擦などの非線形特性を有するものが多く, 不規則入力を受ける振動 系の応答特性は「くせ」のあるいわゆる非ガウス性(non-gaussian)の不規則過程となる.これらのデータの 取り扱いには統計的手法の適用,さらには非ガウス性を考慮した高次統計量(higher order statistics)を用 いた解析が必要不可欠である.

本報告では, 筆者たちが不規則入力を受ける非線形振動系における新しい同定手法として提案してきた高次 スペクトル (Higher Order Spectra;HOS）を用いた非線形振動系の実験解析を行った. 今回は, 実験モデル として, 磁気による反発特性を考慮した改良モデルを製作し, 入力としてサイン波およびランダム加振の実 験を行い、本手法の有効性および検討を行った。これらが今回の報告の骨子である.

\section{2. 高次スペクトル}

高次スペクトルは, 元々は高次のキュムラントの多重フーリエ変換で定義されるが, 実際の計算では, デ 一タの対象性や計算時間などを考慮して, フーリエスペクトルの高次積で算出することが多い. また, これ らのデータ処理については, 前処理やウインドウを掛けたりなどの統計的なデータを精度良くかつ統計的な 誤差を考慮して算出することが重要である.

また, 高次元のデータ処理となるので, 実際の結果を図示化する場合については, 必要とする周波数間の関 倸を定め, その周波数成分間の断面図などを選び，適宜データの低次元化を図ることも必要である. 今回の 報告では, 高次スペクトルの一つであるバイスペトルにトライスペクトルについて取り上げる. 
バイスペクトルとは,「二つの周波数のスペクトル」という意味である(1).パワースペクトルが相関関数の ーフーリエ変換で表されるのに比べて，バイスペクトルは，三次の相関関数の二重フーリエ変換として定義 される.

$$
B\left(f_{1}, f_{2}\right)=\frac{1}{T} E\left[X\left(f_{1}\right) X\left(f_{2}\right) X^{*}\left(f_{1}+f_{2}\right)\right]
$$

\section{ここで,*は複素共役数をあらわす。}

バイスペクトルは 2 次の周波数スペクトルを有し，かつそれぞれの従属関係が存在するときに値に意味を もつ. 上記は一つの変量を取り扱ったもので，オートバイスペクトル (auto bispectrum) という.また入 出力相互の非線形伝達特性をあらわしたものをクロスバイスペクトル (cross bispectrum) という. その特徴の一つは，着目している周波数成分間の従属関係を示していることにある.

これは非線形振動系における高調波，分数調波振動などの主共振の周波数を中心として,他の周波数成分を 含む場合に有効な手法となる.

これらの周波数成分間の特性を示すために，より厳密な形式でスペクトルを論じることが必要である.

時間データ をFoulier-Stieltjes（フーリエ・スチェルチェス）変換を用いて次式のように表示する(2).

$$
x(t)=\int_{-\infty}^{\infty} d X(\omega) e^{j \omega t}
$$

パワースペクトル は，成分 を用いることにより，

$$
\left\langle d X\left(\omega_{1}\right) d X\left(\omega_{2}\right)\right\rangle=\left\{\begin{array}{cc}
P(\omega) & \left(\omega_{1}+\omega_{2}=0\right) \\
0 & \left(\omega_{1}+\omega_{2} \neq 0\right)
\end{array}\right.
$$

となる.つまり, パワースペクトルは，2つの周波数成分の依存性を保持しているが, 物理的に等価な正, 負それぞれの周波数成分同士についての関係を議論していることになる.よって, 単一の周波数成分のみの 特性に限定されるのである. 次に, バイスペクトルについても同様の形式で表現すると次の (4) 式になる.

$$
\left\langle d X\left(\omega_{1}\right) d X\left(\omega_{2}\right) d X\left(\omega_{3}\right)\right\rangle=\left\{\begin{array}{cc}
B(\omega) & \left(\omega_{1}+\omega_{2}+\omega_{3}=0\right) \\
0 & \left(\omega_{1}+\omega_{2}+\omega_{3} \neq 0\right)
\end{array}\right.
$$

周波数表示にした場合、

$$
f_{1}+f_{2}+f_{3}=0
$$

の場合に值をもつことになる。ここでは, 文献(2)に従って, 円振動数 の表現で示している. 周波数 でも

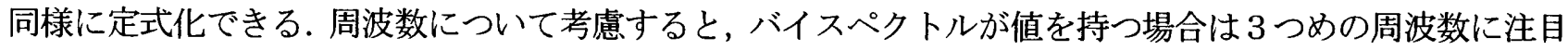
して、

$$
f_{1}+f_{2}+\left(-f_{1}-f_{2}\right)=0
$$

とし， 3 つ周波数の組を考えると 2 つ周波数成分間の従属性を明確にすることが可能である.さらに と置き換えることで 2 倍の高調波成分の従属性も具体的に值を有することになる. 
位相がランダムな場合については，バイスペクトルの值は平均化の過程で值を持たないが，各周波数成分 間に従属性を持ち，なおかつ位相関係が結合している場合にはバイスペクトルは值を有する. パワースペク トルなどにはないバイスペクトルの特徴の一つである.

また，バイスペクトル自身が值の大きさに依存しないようにパワースペクトルで除して基準化したものを 用いて考察を行う場合もある.

著者らは，これを「ひずみ度関数」として名づけている. 次式がその定義式である.

$$
S\left(f_{1}, f_{2}\right)=k \frac{B\left(f_{1}, f_{2}\right)}{\sqrt{P\left(f_{1}\right) P\left(f_{2}\right) P\left(f_{1}+f_{2}\right)}}
$$

係数 $\mathrm{k}$ を 1 として解析に利用している. 類似の概念として、バイコヒーレンシィという定義もある。

著者らは，非線形振動系においてガタを持つ非線形，片側飽和特性など復元力において非線形特性を有す る代表的なモデルについて考察を行ってきた. (3), (4) 高次スペクトルは, 元々は高次のキュムラントの多 重フーリエ変換で定義されるが, 実際の計算では, データの対象性や計算時間などを考慮して, フーリエス ペクトルの高次積で算出することが多い.

また，これらのデータ処理については，前処理やウインドウを掛けたりなどの統計的なデータを精度良く かつ統計的な誤差を考慮して算出することが重要である. さらに一つ次数の高い、高次のスペクトルとして トライスペクトルは,

として定義される.

$$
T\left(f_{1}, f_{2}, f_{3}\right)=\frac{1}{T} E\left[X\left(f_{1}\right) X\left(f_{2}\right) X\left(f_{3}\right) X *\left(f_{1}+f_{2}+f_{3}\right)\right]
$$

バイスペクトルと同様にして周波数同士の組み合わせに注目すると,

$$
f_{1}+f_{2}+f_{3}+f_{4}=0
$$

のときにトライスペクトルは值を持つ。3つの周波数間の従属性を議論していることになる。

もちろん、トライスペクトルは高次元で表示されることになるので計算結果そのままでは、值の評価は わかりにくいことになる。具体的には、注目した周波数成分の組み合わせを眺めて、次元を下げて議論す るのがよい。

非対称特性には偶数次を有するバイスペクトル解析が有効であり、もし、対象型非線形特性を考慮する場 合にはバイスペクトルは值を持たない。このような場合にはトライスペクトルが有効である。

対称、非対称を包含する幅広いクラスの非線形特性を考慮することが可能であるといえる。

\section{1 磁矛反発モデル}

\section{3. 实䀫モデルについて（磁気による反発）}

今回の報告では, 磁石による反発力を利用した実験モデルを製作した(図 1). 以前に製作したモデルより， 可動質量部について軽量化を図っている.
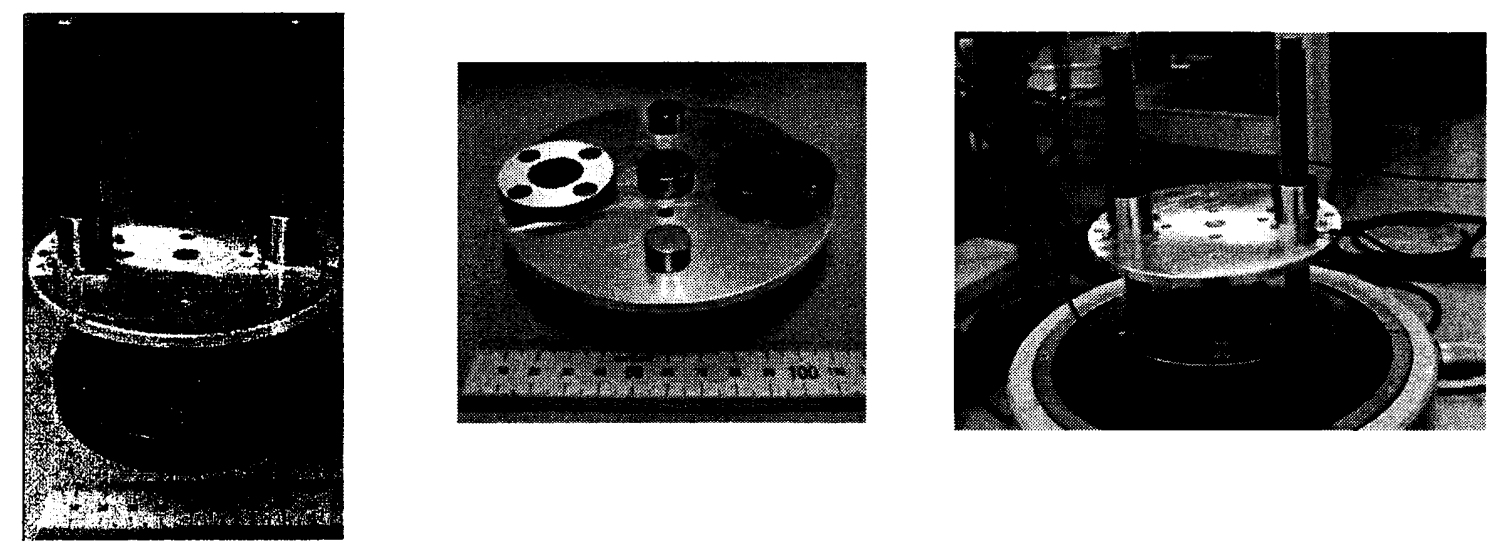

Fig. 1 Experimental model 
可動部分中央に 1 対および円周部分に 2 対のネオジム磁石を取り付けている. 直径が $20 \mathrm{~mm} 、 14 \mathrm{~mm}$ 厚みが $10 \mathrm{~mm}$ (共通), 磁化方向は厚み方向, 表面磁束密度は $430 \mathrm{~m} \mathrm{t}, 480 \mathrm{~m} \mathrm{t}$, 吸着力 $10000 \mathrm{~g}, 6400 \mathrm{~g}$, 質量が

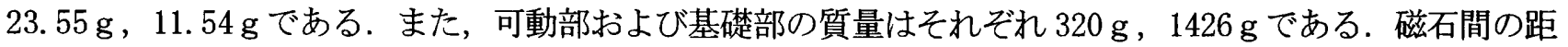
離は静止時において $43.25 \mathrm{~mm}$ として固定して実験を行った。実験測定装置を図 2 に示寸.

入力データは, FFT アナライザにおいて生成され増幅器を通じてサイン波（あるいはランダム波）を入力 として基礎側一加える. そして，基礎側と可動部においては，ねじで締結された加速度ピックアップより加 速度データがそれぞれ測定される.そのデータをもとにしてデータ処理を行った。

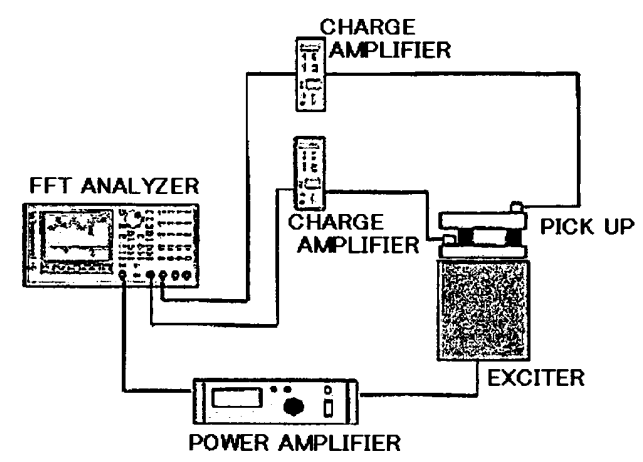

Fig. 2 Experimental apparatus

\section{2 サイン波スイープ実験}

\section{4. 实䠑結果}

サイン波の出力電圧として $2 \mathrm{~V}, 5 \mathrm{~V}, 8 \mathrm{~V}$ として $3 \mathrm{~Hz}$ から $12 \mathrm{~Hz}$ を周波数範囲として上昇および下降スイープ 加振を行った. 周波数応答関数を図 3 に示す. 横軸は周波数, 縦軸は基礎側の加速度を基淮として可動部の加速度 データとの比として示している.

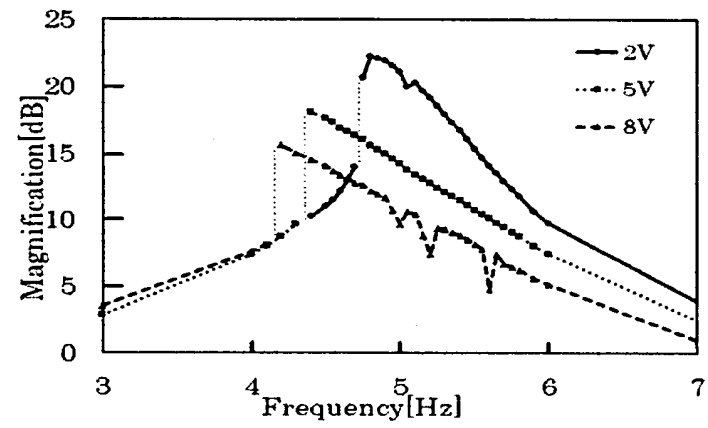

Fig. 3 Nonlinear-FRF

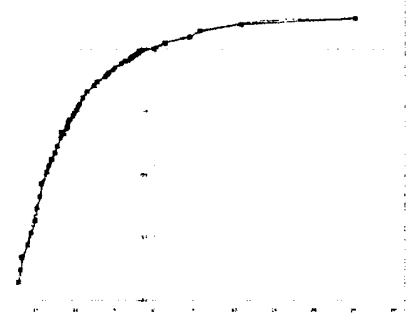

Fig. 4 Curve-Fitting(Stiffness)

共振曲線は左に傾く非線形特性として特徵的な「ソフトばね」の傾向を示していることがわかる.

つぎに，磁石による反発力に相当する非線形剛性（ばね定数）を実験により推定した. 磁石間距離と荷重との関 係を図 4 のようにプロットしてカーブフィット（曲線適合）を行った. 主な特徵としては，変位の 5 乗項までを 含めた推定がもっとも当てはまりが良いようである（残差二乗和 : R2 值として 0.998).

\section{3 ランダム加振実験}

ランダム波を入力してそのときの実験結果をまとめた．図 5 にパワースペクトル結果を示す. 主共振ピークは $5 \mathrm{~Hz}$ 近辺そして低次の $2 \mathrm{~Hz}$ 近辺にもピークが存在していることがわかる.

出力電圧を $2 \mathrm{~V} ， 5 \mathrm{~V} ， 8 \mathrm{~V}$ などと大きくしていくとわずかながら主共振ピークは $5.5 \mathrm{~Hz}$ から $5.2 \mathrm{~Hz}$ と低 い周波数へ移動していくことも観察された. 


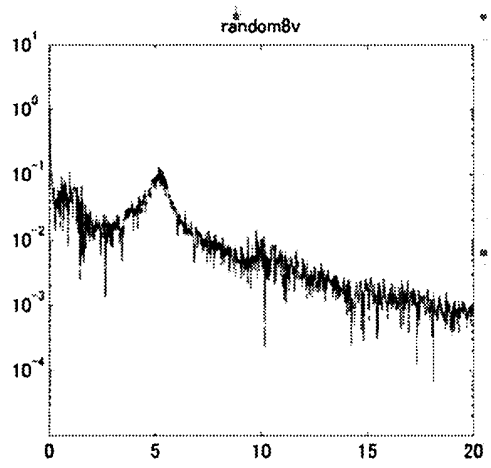

Fig. 5 Power Spectrum

\section{4 パイスペクトル解析による考察}

一例として，入力電圧が $5 \mathrm{~V}$ のきの基碟側（下段），可動部側（上段）の加速度波形を図 6 に示す. 次に, 応答加速度（相対）についてバイスペクトル解析（振幅の絶対值）を行った(図 7 ). 二つの周波数軸として大きさを高さ方向の軸として表示している.上方からみた等高線図をあわせて 図 8 に表示寸る.
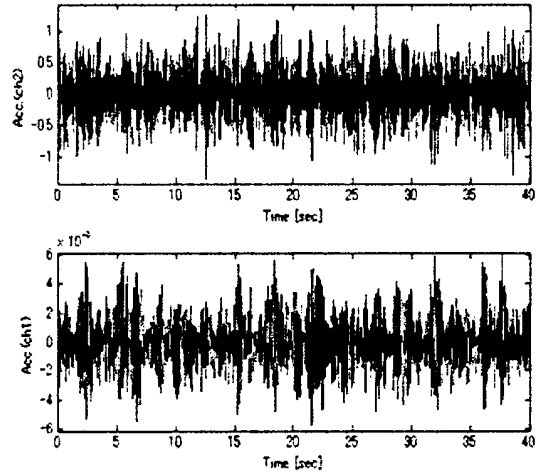

Fig. 6 Time of history data

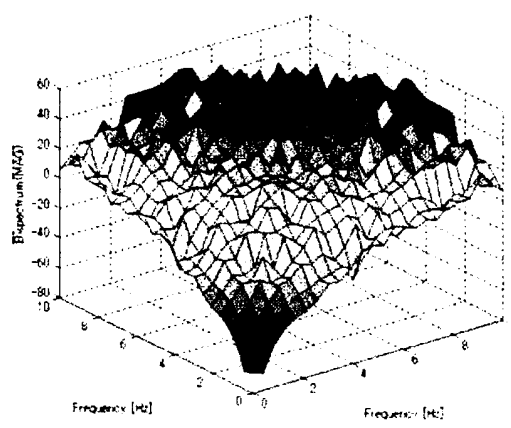

Fig. 7 Bispectrum(Magnitude)

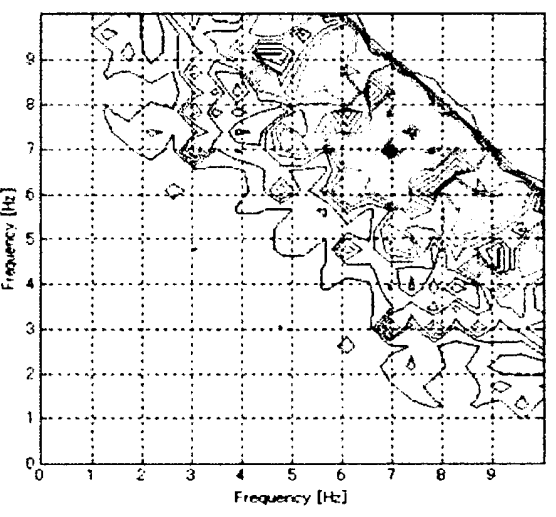

Fig. 8 Contour map(Bispectrum)

基本波と 2 倍周波数の関係を考察するため出力電圧（2V, $5 \mathrm{~V}, 8 \mathrm{~V})$ と変化したときのひずみ度関数を図 9 に示す. これらの結果を考察すると, およそ $2 \mathrm{~Hz}, 5 \mathrm{~Hz}$ および $7 \mathrm{~Hz}$ 付近との間で和差調和波に相当する周波数成分間の従属 性がランダム入力による高次スペクトル解析から明らかになった.

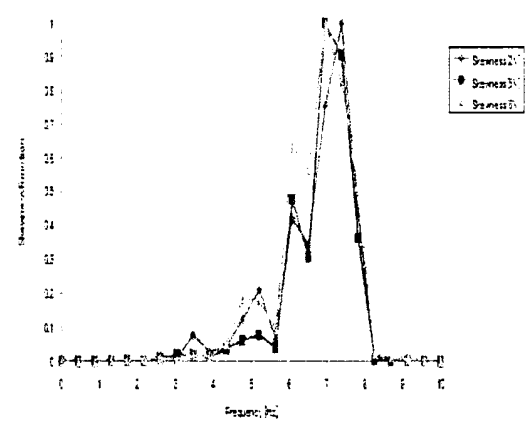

Fig. 9 Skewness Function 


\section{1 ストッパ付きモデル}

\section{4. 实験モデルについて（ストッパ付きモデル）}

本研究で用いるストッパ付きモデルを説明する（図 10）。このモデルは, 加振機側プレート (以後, 加振機 側とする) と主軸, 金属ばね, 応答側プレート (以後, 応答側プレートとする), ゴム製ストッパとストッパ台座, ばね固定治具で構成されている.

金属ばねの上端を応答側に固定し, 下端を加振機側に固定した. 主軸にねじ加工を施し, ストッパ台座の高 さが自由に変えられる. 加振すると応答側が変位し, 金属ばね内部のストッパに衝突する.
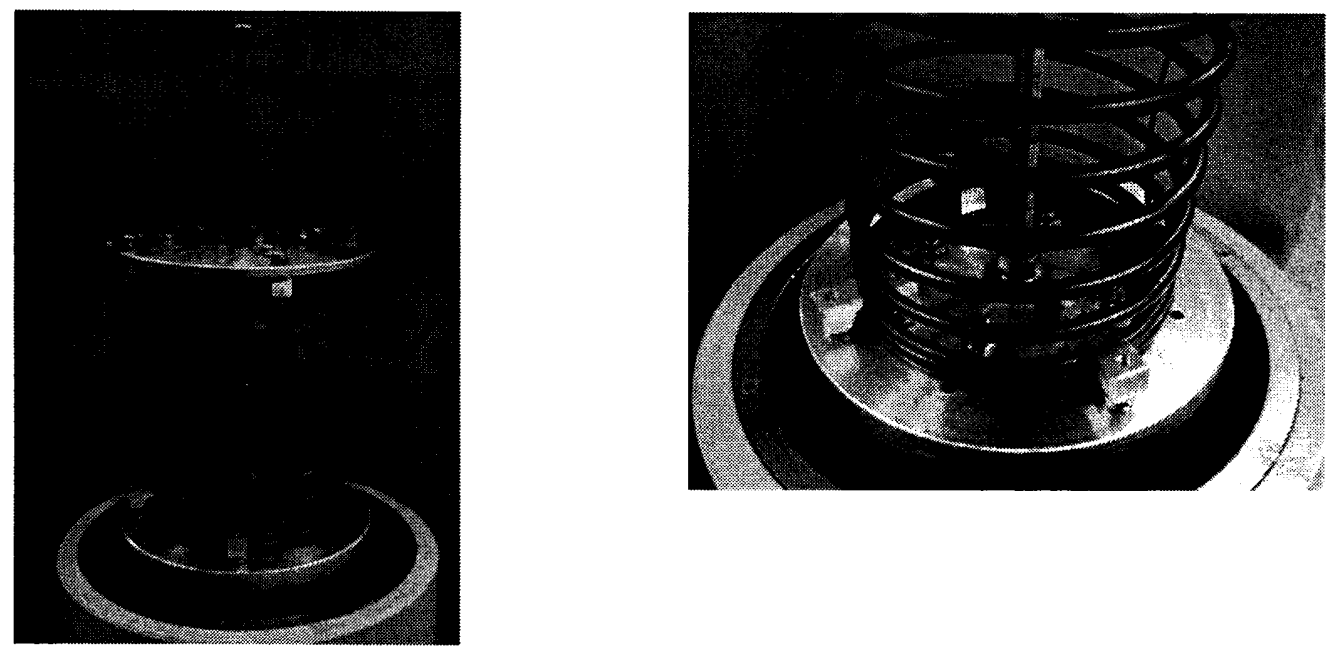

Fig. 10 Experimental Model (Magnetic model)

\section{2 实験結果}

サインスイープ加振を行い、出力電圧を $0.7 \mathrm{~V}$ から $2.5 \mathrm{~V}$ までの変化させたときの応答側データの結果を図 11 に示す．電圧の大きさが大きくなるのに対応して，共振周波数の位置が高い周波数側へシフトすることが図より わかる。これらのことにより、ハードばねの傾向をしめしていることが推察される.

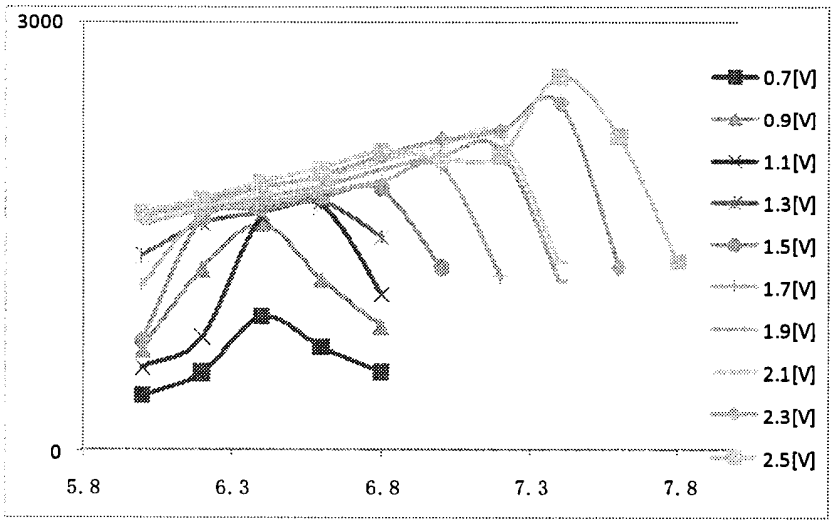

Fig. 11 Sine sweep (Magnetic model)

つぎに，バイスペクトル解析の結果を示す. ランダムデータをこの実験モデルに加えた. 出力電圧を変化

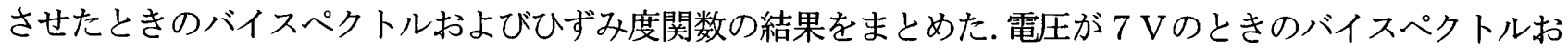
よびひずみ度関数の結果を図 12 および図 13 に示す. 


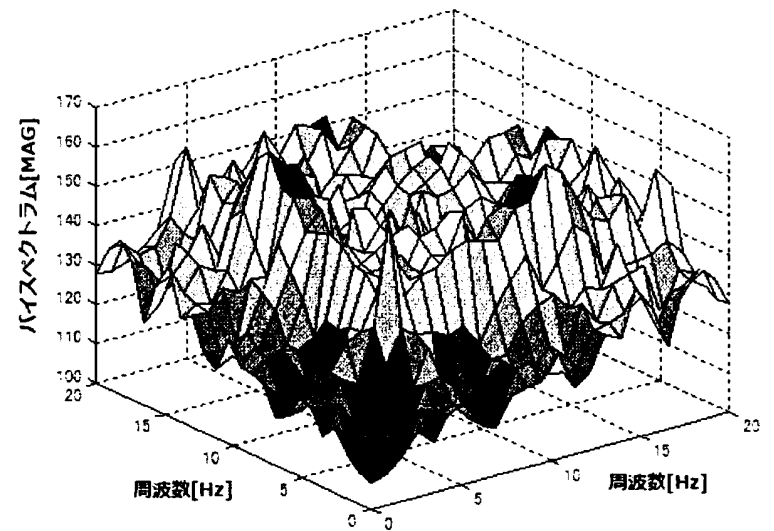

Fig. 12 Bispectrum (Magnetic mode1)

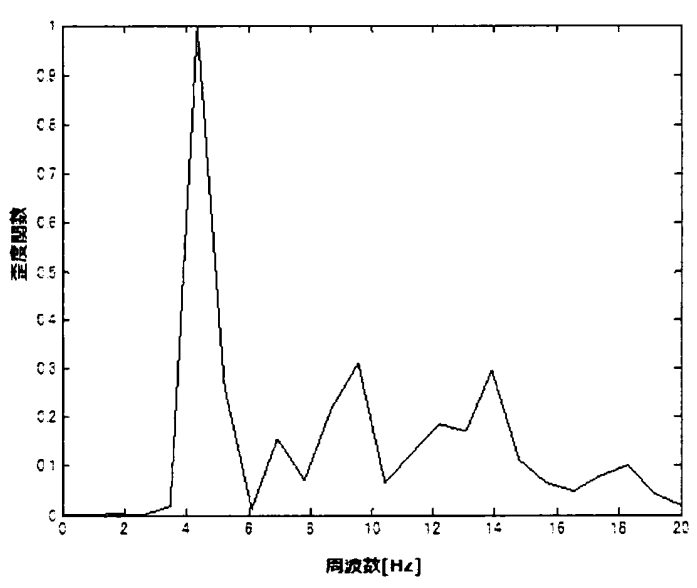

Fig. 13 Skewness function (Magnetic mode1)

$4 \mathrm{~Hz}$ 付近にひずみ度関数のピークが目立つことから $4 \mathrm{~Hz}$ と $8 \mathrm{~Hz}$ の間に周波数成分の従属性があることがわ かる．その他、2 倍の関係のみならず， 3 倍の周波数成分についても従属性があることがいえる.

出力電圧については上昇させた影響を考察したが、大幅に共振周波数ピークが移動することはなかった.

\section{5. まとめ}

磁気による反発力およびストッパ付きモデルを非線形特性として有する 2 つ実験モデルを製作し, 高次ス ペクトル解析の一つであるバイスペクトルにより周波数成分間の従属性を明らかにした. 実稼働時における 不規則データに埋もれていても特徴のあるデータを抽出できる利点を生かし, さらなる有効性を提示すると もに多くの非線形モデルへの検討を行っていく.

\section{文献}

(1) 松本, 山川, 大石 : 機論 $\mathrm{C}$ 編, 62 巻 604 号

(2) 日野幹雄: スペクトル解析, 朝倉書店, p 246- 254.

(3) 松本, 山川, 大石 : D\&D2010

（4）芝崎, 2010 年度工学院大学卒業論文, 2011

(5) 村岡, 2010 年度工学院大学卒業論文, 2011 